\title{
Pravěké osídlení Šatova (okr. Znojmo)
}

\section{Prehistoric occupation of Šatov (Znojmo District)}

\section{David Rožnovský}

\begin{abstract}
Abstrakt
Předkládaná práce představuje krátký exkurz do pravěkého osídlení obce Šatova, který shrnuje doposud známé archeologické nálezy od paleolitu po starší dobu železnou. První pozůstatky prehistorického osídlení byly $\vee$ Šatově odkrývány již na konci 19. století během těžby cihlářské hlíny. Nejpočetnější pravěké památky tvoří nálezy ze starší doby bronzové. Na šatovském katastru evidujeme hned několik poloh s doklady únětické kultury.
\end{abstract}

\section{Klíčová slova}

Šatov (okr. Znojmo); pravěk; osídlení; sídliště; pohřebiště

\begin{abstract}
The article provides a short insight into prehistoric settlement in the area of Šatov village. It summarizes the hitherto known archaeological finds from the Palaeolithic until the Early Iron Age. The first relics of prehistoric occupation were already uncovered at Šatov at the end of the 19th century during extraction of brick clay. Prehistoric relics most frequently date back to the Early Bronze Age. In the cadastral district of Šatov we identify several sites with evidence of the Únětice Culture.
\end{abstract}

\section{Key words}

Šatov (Znojmo District); prehistory; occupation; settlements; cemeteries 


\section{1. Úvod}

Obec Šatov je známá především výrobou keramického zboží, která zde probíhala od počátku 70. let 19. století a byla ukončena v r. 1998 (Piscová 2020, 7, 22, 83). Vzhledem ke značné spotřebě cihlářské hlíny docházelo $\mathrm{v}$ blízkosti továrny situované těsně u šatovského nádraží k rozsáhlé těžbě spraše. Spraš byla ve východní části katastru těžena v omezené míře již v druhé polovině 19. století. Kvưli dlouhodobé těžařské činnosti bylo od samotného počátku ničeno značné množství archeologických nálezů, které se pokoušel zachraňovat např. učitel z nedalekého Unterretzbachu L. Mattula, znojemský notář J. Palliardi a řada dalších (obr. 1). Nejrozsáhlejší archeologické výzkumy zde bohužel začaly probíhat až od počátku 60. let, kdy bylo v šatovském hliníku V. Vildomcem prozkoumáno kolem 130 zahloubených objektů spadajících do období únětické kultury. Terénní dokumentace z Vildomcových výzkumů byla považována za ztracenou (Kañáková-Hladiková 2011-II, 361), nicméně v roce 2020 byla objevena, spolu s dalšími materiály vázanými $\mathrm{k}$ archeologickým výzkumům v Šatově, ve Státním okresním archivu ve Znojmě.

\section{Poloha zkoumané lokality a geologické poměry}

Obec Šatov se nachází zhruba šest kilometrů JJZ od města Znojma na okraji Národního parku Podyjí a necelé dva kilometry S od hranic s Rakouskem. Městys leží ve sníženině potoka Daníže a na okraji členitého pobřežního prahu (Pavelková 2021, 1). Zkoumané lokality jsou situovány na východní straně katastru a převážnou část $\mathrm{z}$ nich najdeme na pravém břehu Daníže (obr. 2). Z geomorfologického hlediska leží širší území zkoumaných lokalit na styku Českomoravské vrchoviny a Dyjsko-svrateckého úvalu.
Území západně od Šatova je tvořeno zvlněnou Znojemskou plošinou, která se prostírá po obou březích Dyje až k Načeraticím. Území směrem na východ náleží k Jaroslavické pahorkatině, jež je součástí karpatské předhlubně. Skalní podklad je tvořen biotitickým granodioritem dyjského masivu, který směrem k jihu přechází v biotitický granit s vložkou žilných hornin. Na tento podklad byly uloženy miocenní sedimenty karpatské předhlubně $\mathrm{v}$ podobě mořských i brakických písků a vápnitých jílů, které dosahují celkové mocnosti 400-500 m. Pleistocenní fluviální písčité štěrky v údolí Daníže a plošně nejrozsáhlejší sedimenty spraší, které pokrývají celé území jihovýchodně od okraje Českého masivu, dokládají ukončení geologického vývoje v období kvartéru, a to sedimentací výše zmíněných fluviálních, lakustrinních a eolických sedimentů. Největší mocnosti spraší byly zjištěny jednak v okolí Šatova, ale i v okolí Hatí, jihovýchodním okolí Znojma a jihovýchodně od Chvalovic. Spraše tvoří podklad pro orné půdy. Ty jsou vyvinuty na pruzích závětrných sprašových akumulací zhruba jižně od Nového Šaldorfa a východně od Šatova s tím, že nejkvalitnější a nejcennější půdy představují černozemě $(\mathrm{Pa}$ velková 2021, 2-3).

\section{Přehled osídlení od paleolitu po starší dobu železnou}

\subsection{Paleolit}

Nejstarší známé šatovské nálezy datujeme do mladopaleolitické kultury aurignacienu (Podborský - Vildomec 1972, 215) a poprvé byly zaznamenány na počátku března roku $1908 \mathrm{v}$ cihelně T. Grüblera (můžeme se setkat i s přepisem příjmení ve formě Griebler). Během těžby spraše byly v hloubce pěti metrů objeveny stoličky mamuta a kosti jiných zvírat spečené s hrubozrnným pískem. Spolu s kostmi byla spraší přikrytá 
Náxen'en' pane rèduteli?

$$
\text { r. 1939!' }
$$

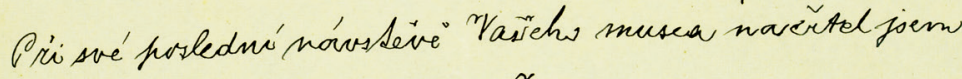
si skizou hrobutch náiob ze Salorra,

- dibán a amforcu s puptay ma vy duch'.

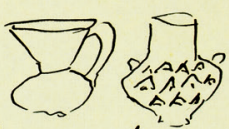

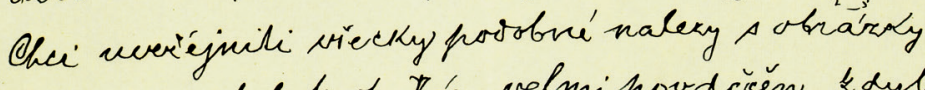
z keravy a byl byih Tám velmi povdčén, \&dyby ste mi mohli wakresliti jew turiserw obe tyto nairo.

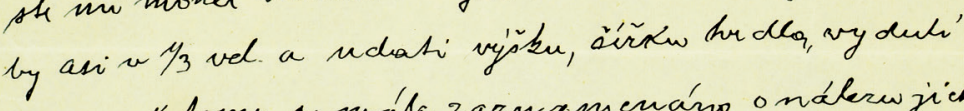
a dma, a K Aomm, cu mále zarmamenáno o nálerw jich

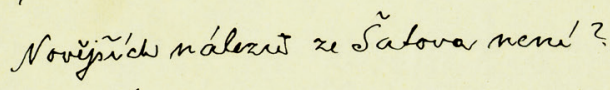
Q érheje fiée dam wa ochertar

$$
\begin{aligned}
& \text { ufflne' u'che } \\
& \text { QX) y. Q Qurinim }
\end{aligned}
$$

Obr. 1. Korespondence I. L. Červinky vázaná k nálezům z Šatova. Zdroj MZA Brno, SOkA ve Znojmě, Fond Jihomoravské muzeum Znojmo, karton 13, inv. č. 865, fol. 2.

Fig. 1. Correspondence of I. L. Červinka regarding the finds from Šatov. Source: Moravian Archive in Brno, State District Archive in Znojmo, Fonds Jihomoravské muzeum Znojmo, box 13, Inv. No. 865, fol. 2. 


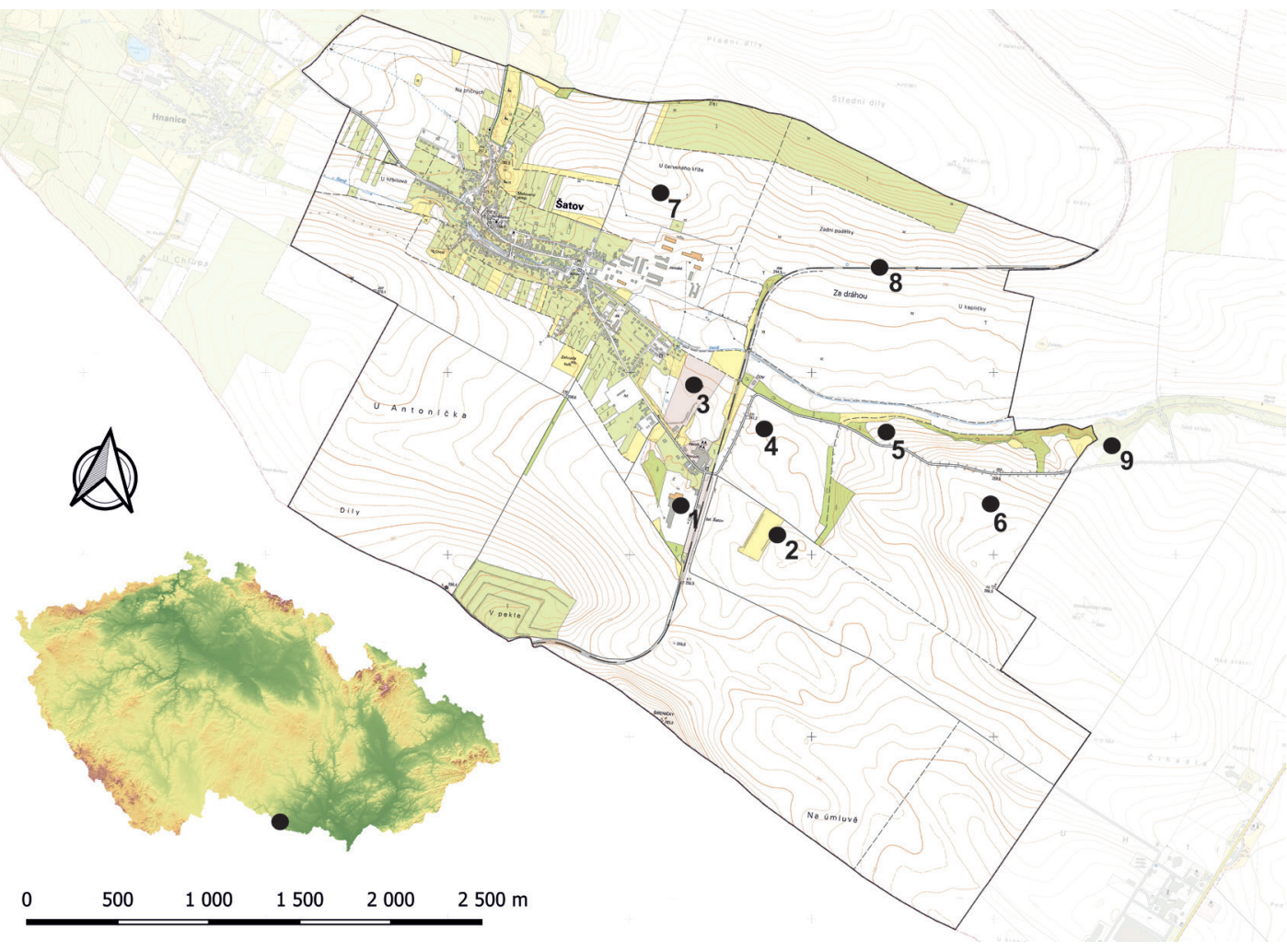

Obr. 2. Základní mapa Šatova a blízkého okolí s vyznačenými lokalitami. 1 - keramický závod, 2-4 - cihelny/ hliníky keramického závodu (číslo 3 je zároveň bývalá Grüblerova cihelna), 5 - bezejmenná trat', 6 - Hochfeld, 7 - U červeného kříže, 8 - Unzendorfer, 9 - Chvalovice-pískovna.

Fig. 2. Base map of Šatov and its close surroundings with marked sites. 1 - ceramics factory; 2-4 - brickworks/ clay pits of the ceramics factory (number 3 at the same time signifies former Grübler brickworks); 5 - nameless plot of land; 6 - Hochfeld; 7 - U červeného kř́že; 8 - Unzendorfer; 9 - Chvalovice-sandpit.

také tenká uhlíková vrstva. O nálezu byl informován učitel L. Mattula z nedalekého Unterretzbachu, bohužel př́iliš pozdě, a podařilo se mu zachránit jen několik kostí (Bayer 1925, 68; Wieder 1925, 6). O několik let později bylo objeveno několik mamutích stoliček a kostí zhruba 500 metrů od původního nálezu. Další nálezy paleolitického stáří byly zachyceny v r. 1924 přibližně 100 metrů od nálezu z roku 1908 (Bayer 1925, 68). Na začátku března r. 2020, tedy 112 let od prvního oficiálně známého paleoli- tického nálezu, byl autor přivolán $\mathrm{k}$ nálezům kostí zvírat odkrytým během budování základů pro opěrnou zed'. Naleziště se nachází Z a JZ směrem zhruba 200 metrů od bývalé Grüblerovy cihelny, na samé hraně staré těžní stěny (p.č. 1109/5). Osteologický materiál byl zjištěn v hloubce čtyř metrů od úrovně současného povrchu. Bohužel tak jako v předchozích případech se u kostí nenacházely žádné kamenné nástroje či jiné předměty, které by dovolily bližší datování. 

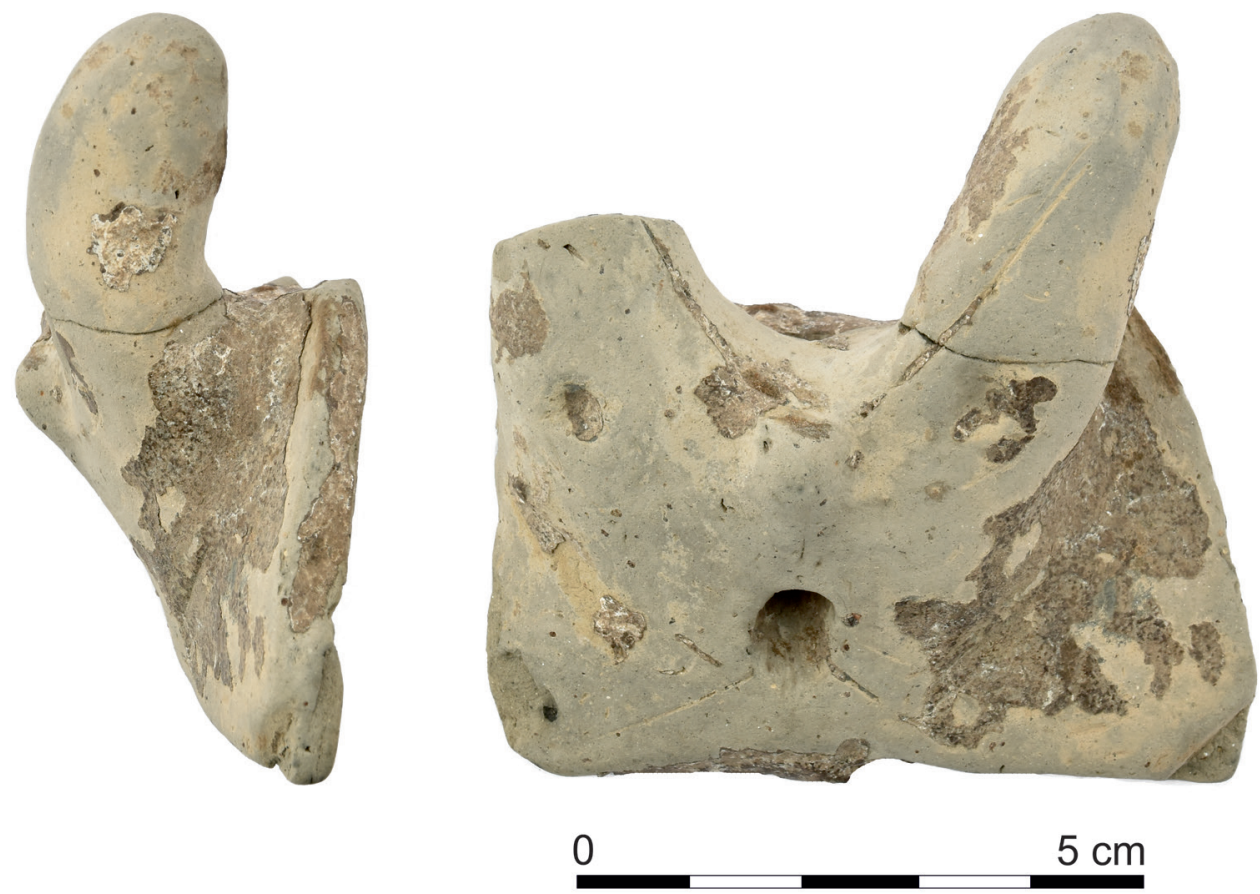

Obr. 3. Šatov. Střep LnK s plastickou aplikací. Foto autor.

Fig. 3. Šatov. Fragment of Linear Pottery with a lug-shaped appliqué. Photo by author.

\subsection{Neolit a eneolit}

Z období neolitu a eneolitu nejsou z Šatova známa nikterak rozsáhlá naleziště. Pozůstatky možná většího neolitického sídliště zmiňuje krátkou zprávou J. Palliardi, který jednou větou uvádí, že v roce 1893 byly v cihelně u šatovského nádraží objeveny neolitické sídlištní jámy (Palliardi 1894, 33). Nálezy z porušeného sídliště kultury s lineární keramikou měl J. Palliardi uloženy ve své soukromé sbírce (Palliardi nedat., 61). Několik střepů LnK z šatovských cihelen se nachází také ve znojemském muzeu (Böhm 1933). Zajímavý nález z období LnK je střep z nádoby s aplikovanou zoomorfní plastikou, či spís s uchem vymodelovaným do podoby stylizované hlavy býka nebo kozla (?). Oči jsou vyve- deny notovými značkami, mezi nimi vystupuje čumák, z jehož horní části vychází tenká linie, která pokračuje do dvou třetin rohů. Další ryté linie se nachází na spodní části výčnělku a pod ním. Zoomorfní výčnělek je protknut vertikálním otvorem (obr. 3). Analogie k šatovskému nálezu bychom mohli hledat např. v nedalekých Tešeticích (Vostrouská 2018, tab. 60:8) či na slovenské lokalitě Hurbanovo-Bohatá (Březinová - Pažinová 2011, 95, tab. II:3). V rozsáhlých cihelnách byly objeveny také pozůstatky kultury s moravskou malovanou keramikou (Palliardi nedat., 61; Vildomec 1931, 8). Z blíže neurčeného místa pak pochází dvě rohatá ucha z větší nádoby MMK objevená v r. 1965. Do neolitu můžeme zařadit nálezy z povrchových sběrů východně od obce, na hranici katastrů Chvalovic 


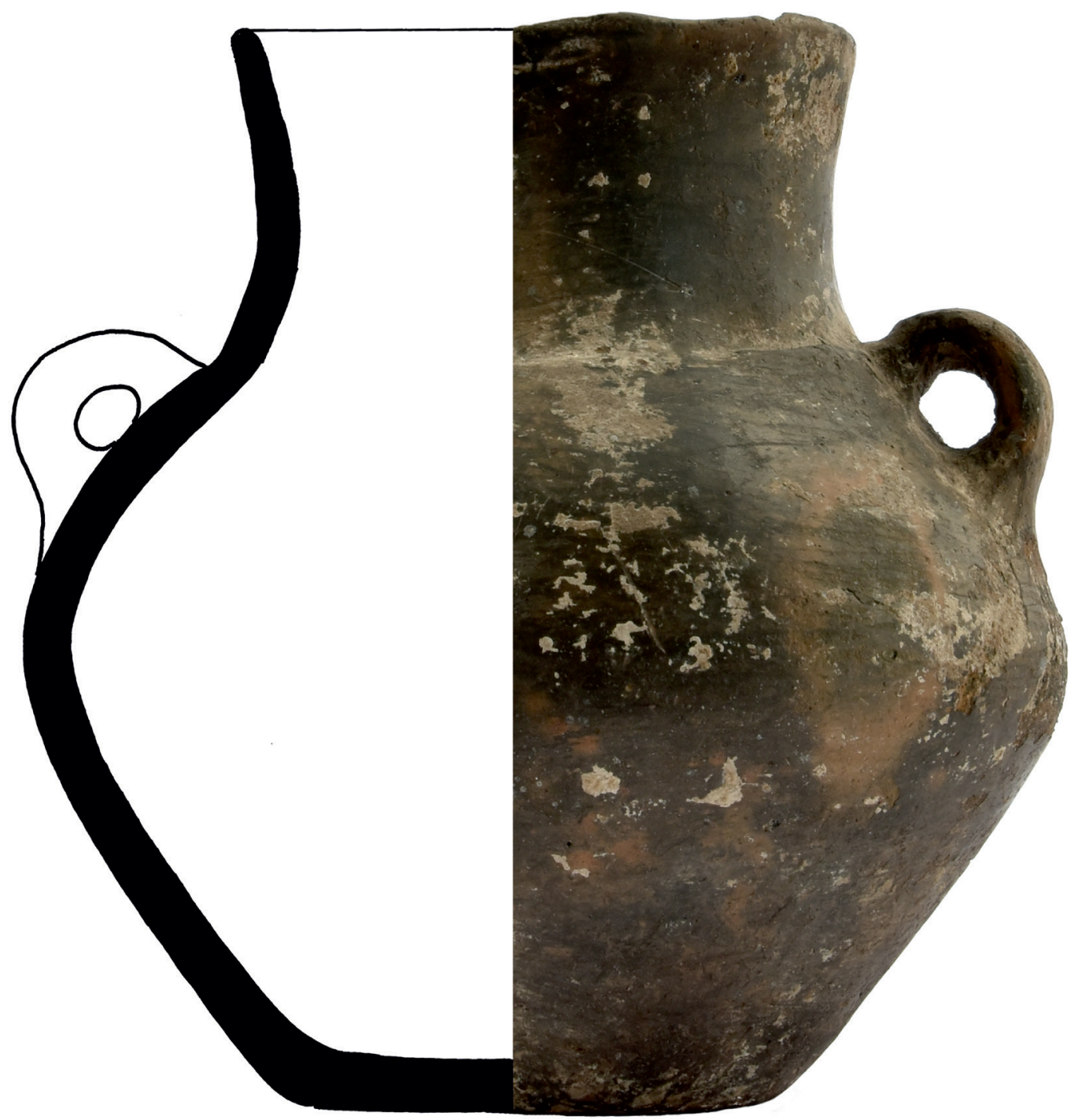

Obr. 4. Šatov. Dvouuchá amforka KNP. Kresba R. Hetflaiš, foto autor.

Fig. 4. Šatov. Two-handled amphora of the Funnel Beaker Culture. Drawing by R. Hetflaiš, photo by author. 
a Šatova po pravé straně silnice spojující zmíněné obce (Kovárnik 1984, 98).

Z blíže neurčeného naleziště z katastru Šatova se ve sbírkách znojemského muzea nachází dvouuchá amfora, kterou M. Zápotocký (1957, 227) řadí do období kultury nálevkovitých pohárů (inv. č. 1451, obr. 4) ze staršího úseku pozdní doby kamenné. Nádoba má hrdlo oddělené jemnou hranou, pod kterou jsou na plecích nasazena dvě pásková ouška (Zápotocký 1957, 225, obr. 106). Pokud by se jednalo o nádobu KNP, z chronologického hlediska ji můžeme zařadit do předbaalberského stupně s tím, že tento typ keramiky doznívá na počátku baalberského stupně (Šmíd 2017, 167). Oproti M. Zápotockému klade tuto nádobu S. Stuchlik (1979-II, 178) až do střední doby bronzové. Kvůli blízké podobnosti popisované nádoby v obou obdobích a díky neznámým nálezovým okolnostem je otázkou diskuze, jestli nádoba spadá do KNP, či až do SDMK.

\subsection{Doba bronzová}

Předchozím krátkým výčtem nálezů se víceméně uzavírají znalosti o osídlení Šatova v mladší a pozdní době kamenné. Podle dosavadních poznatků by zde měl nastat poměrně dlouhý hiát a další osídlení se na tomto území začíná objevovat až na samém konci eneolitu a na počátku starší doby bronzové. Je otázkou, zda tomu tak bylo i ve skutečnosti, či zda se jedná pouze o stav výzkumu.

$\mathrm{S}$ nastupující dobou bronzovou se počet lokalit a nálezů z katastru obce začíná rapidně zvyšovat. Známá sídliště únětické kultury a věteřovské skupiny se vyskytují ve východní části katastru. To je, jak už jsme zmínili výše, dáno především tím, že $\mathrm{v}$ těchto místech probíhala intenzívní těžba spraše, díky čemuž docházelo k četnému porušování archeologických situací. V ostatních částech sledovaného území se se stavební a těžební činností téměř nesetkáváme.

Zastoupení nálezů zejména únětické kultury je velmi silné. Setkáváme se zde zejména s pozůstatky sídlišt́, známý je jeden depot. Představu o osídlení únětickou kulturou nám doplňují ojedinělé nálezy keramiky a bronzové industrie. Památky únětické kultury se objevovaly od samého počátku těžby hlíny v této části obce (Wieder 1925, 8). Z chronologického hlediska nejstarší nálezy, které spadají ještě do závěru eneolitu, představuje odkryv kostrového hrobu protoúnětické kultury zhruba jeden kilometr $\mathrm{V}$ směrem od železniční stanice $\mathrm{v}$ trati Hochfeld $^{1}$ z r. 1954. Z výbavy hrobu se podařilo zachránit dva větší hrnky, jednu misku a několik střepů z další nádoby (Ondráček 1967a, 433; týž 1967b). Jisté nejasnosti ohledně lokalizace panují v př́ípadě nálezu šálkovitého hrníčku, který je uložen v Moravském zemském muzeu v Brně (inv. č. 54 209).J. Ondráček (1967b) uvádí jako místo nálezu „Hohes Feld“ (viz pozn. č. 1) a v závorce pak trał „Tiefe Wiese“. Zmiňované tratě jsou situovány na samém okraji $\mathrm{V}$ části katastru. Prvně jmenovaná poloha leží na mírném návrší po pravé straně silnice vedoucí do Chvalovic, zatímco druhá leží v nivě na levém břehu potoka Daníže. Mezi šatovským inventářem pocházejícím z blíže neupřesněné polohy se nachází také protoúnětická bezuchá amforka s nízkým hrdlem (inv. č. A 1459), které plynule přechází v kulovité tělo (Kovárnik 1999b, 202, tab. III:8). Analogie k této nádobě můžeme hledat mezi nálezy ze Syrovic, Božic nebo z Maref (Ondráček 1967, obr. 27:6; 9:1, obr. 18:2, 10).

Únětické sídliště porušené těžbou hlíny bylo objeveno také v roce 1954. Nejprve pracovníci Jihomoravského muzea ve Znojmě vyzvedli několik keramických nálezů a lidskou kostru, následně výzkum přebírá Archeologický ústav tehdejší ČSAV v Brně. Na ploše skryté buldozerem bylo zjištěno zhruba 30 porušených zahloubených objektů. Kromě toho byl jeden objekt vybrán pracovníky keramičky. Během výzkumu 


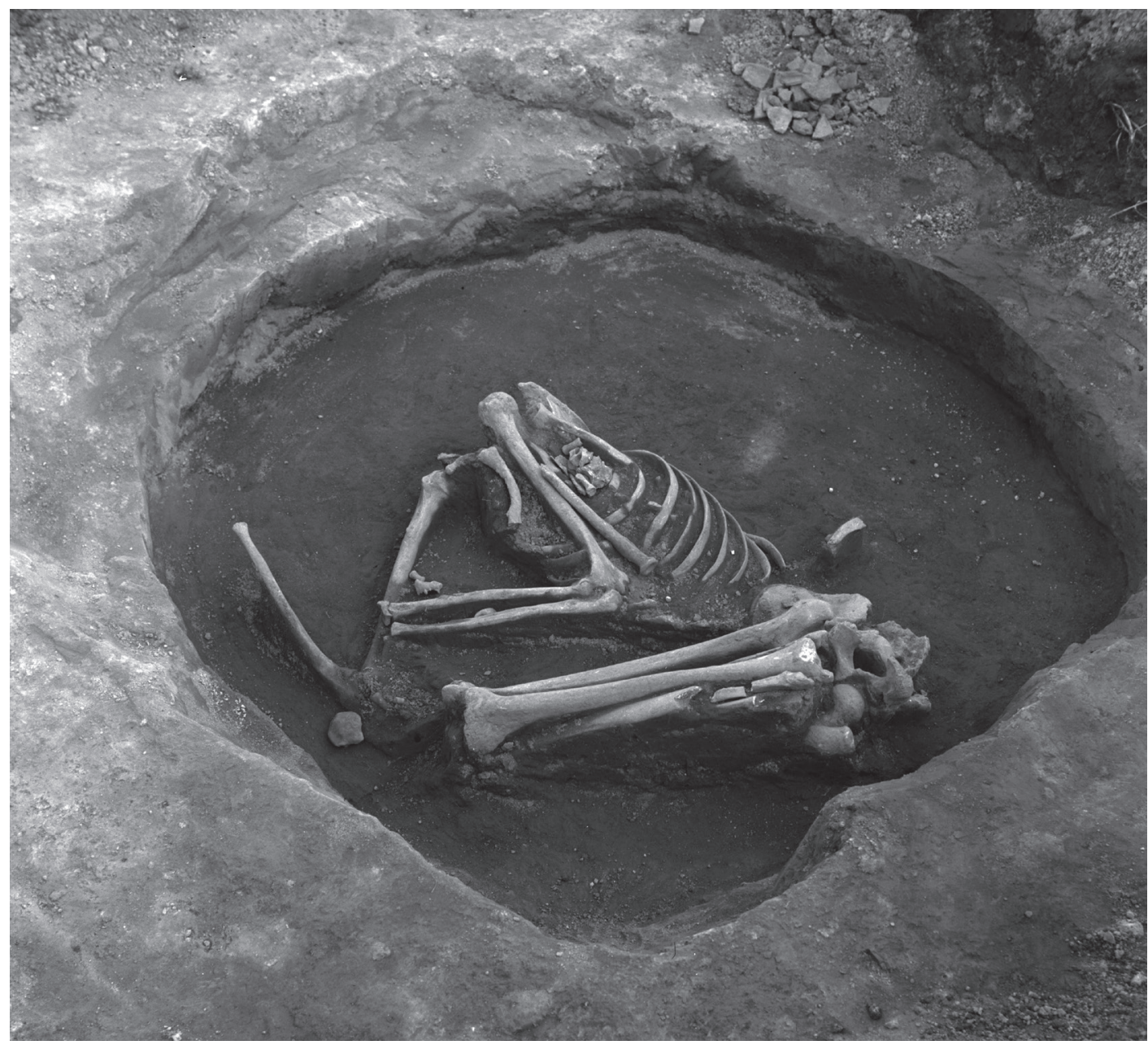

Obr. 5. Šatov - hliník keramičky. Snímek lidského pohřbu v zásobní jámě z výzkumu v r. 1954. Zdroj Archiv AÚ AV ČR Brno, inv. Č. M-FT-100479900.

Fig. 5. Šatov - clay pit of the ceramics factory. Human burial in a storage pit, a photo from the excavation in 1954. Source: Archive of the Institute of Archaeology, Czech Academy of Sciences in Brno, Inv. No. M-FT100479900.

AÚ byla prozkoumána zásobní jáma kruhového půdorysu, v jejímž zásypu byla objevena lidská kostra ve skrčené poloze na pravém boku s hlavou k východu (obr. 5; Král 1954, 1-2, Foto 1-3). Obdobně jako v případě Ondráčkem popisovaného protoúnětického nálezu, také $\mathrm{u}$ tohoto výzkumu narazil autor předkládaného textu na nesrovnalosti v lokalizaci uváděné v citované nálezové zprávě J. Krále, ale i v souborném díle věnovaném pravěku Znojemska (Podborský
- Vildomec 1972, 215). V obou pracích je mylně zmiňována trat’ „Unzendorfer“, na které ale těžba cihlářské hlíny neprobíhala. Navíc z popisu J. Krále $(1954,1)$ je patrné, že pravěké objekty byly porušeny v cihelně ležící na pravém břehu potoka Daníže po pravé straně silnice vedoucí do obce Hnanice. Zmíněná poloha „Unzendorfer“ pojmenovaná po zaniklé osadě se nachází na levé straně potoka přibližně v místech dnešních tratí „Zadní padělky“ a „Za dráhou“ a úně- 


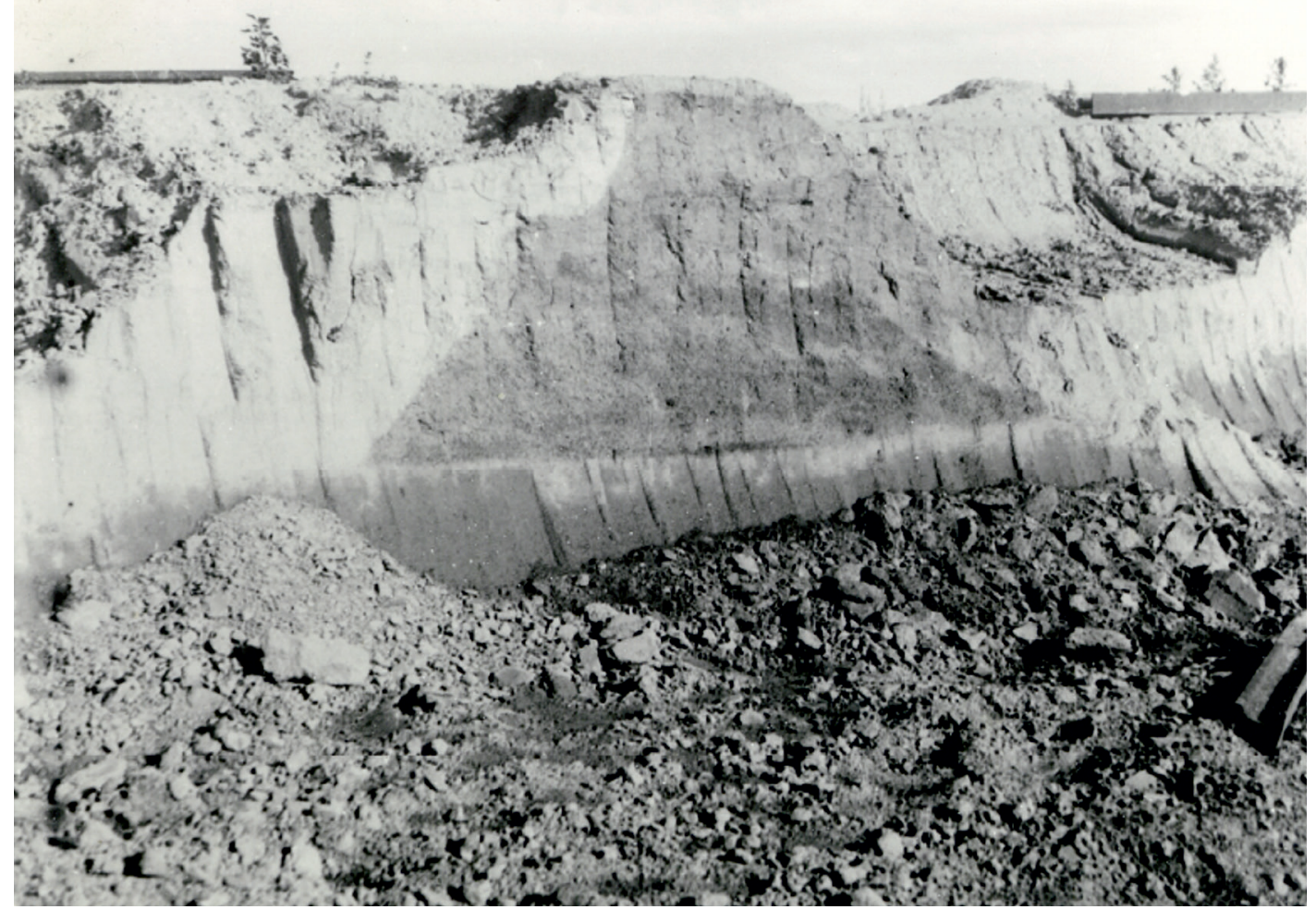

Obr. 6. Šatov - hliník keramičky. Profil porušené zásobní jámy ÚK zkoumané v r. 1962. Podle Vildomec 1962.

Fig. 6. Šatov - clay pit of the ceramics factory. Cross-section of a disturbed storage pit of the Únětice Culture, explored in 1962. After Vildomec 1962.

tické nálezy jsou zde známy pouze z povrchových sběrů (Tihelka 1962b, 2).

I když se v místech zmíněné cihelny pokračovalo v těžbě, během které byly patrně porušovány četné archeologické objekty, uskutečnil se další archeologický výzkum na lokalitě až o několik let později. ${ }^{2} \mathrm{~V}$ roce 1961 byl V. Vildomec upozorněn na porušování sídlištních objektů a snad i hrobů únětické kultury, ke kterému dochází během těžby spraše. Vzhledem k tomu, že k výrobě šatovské keramiky musela být spraš naprosto čistá, nebyly různě poškozené objekty zcela odbagrovány a místa s nimi byla vynechávána, takže se tvořily malé pahorky. Po dohodě s keramickými závody byl následujícího roku Jihomoravským muzeem ve Znojmě proveden zá- chranný archeologický výzkum (Vildomec 1961). Během letních měsíců r. 1962 bylo prozkoumáno asi 130 sídlištních objektů (obr. 6), v některých př́padech s lidskými pohřby (Vildomec 1962). Svou materiálovou náplní osada nevybočuje nad rámec soudobých lokalit (obr. 7). Z chronologického hlediska lze část sídliště zařadit do starší a část do mladší únětické kultury (Stuchlik 1972, 159, 165). Další dva objekty byly v místních hlinících zdokumentovány v r. 1969 (Štaffová 1969). Během všech výzkumů prováděných na šatovském sídlišti bylo prozkoumáno cca 180 objektů, což z lokality u Šatova činilo největší známé moravské sídlišš̌ únětické kultury (Stuchlik 1993, 249). O tento primát přišla lokalita díky boomu stavební činnosti patrné 

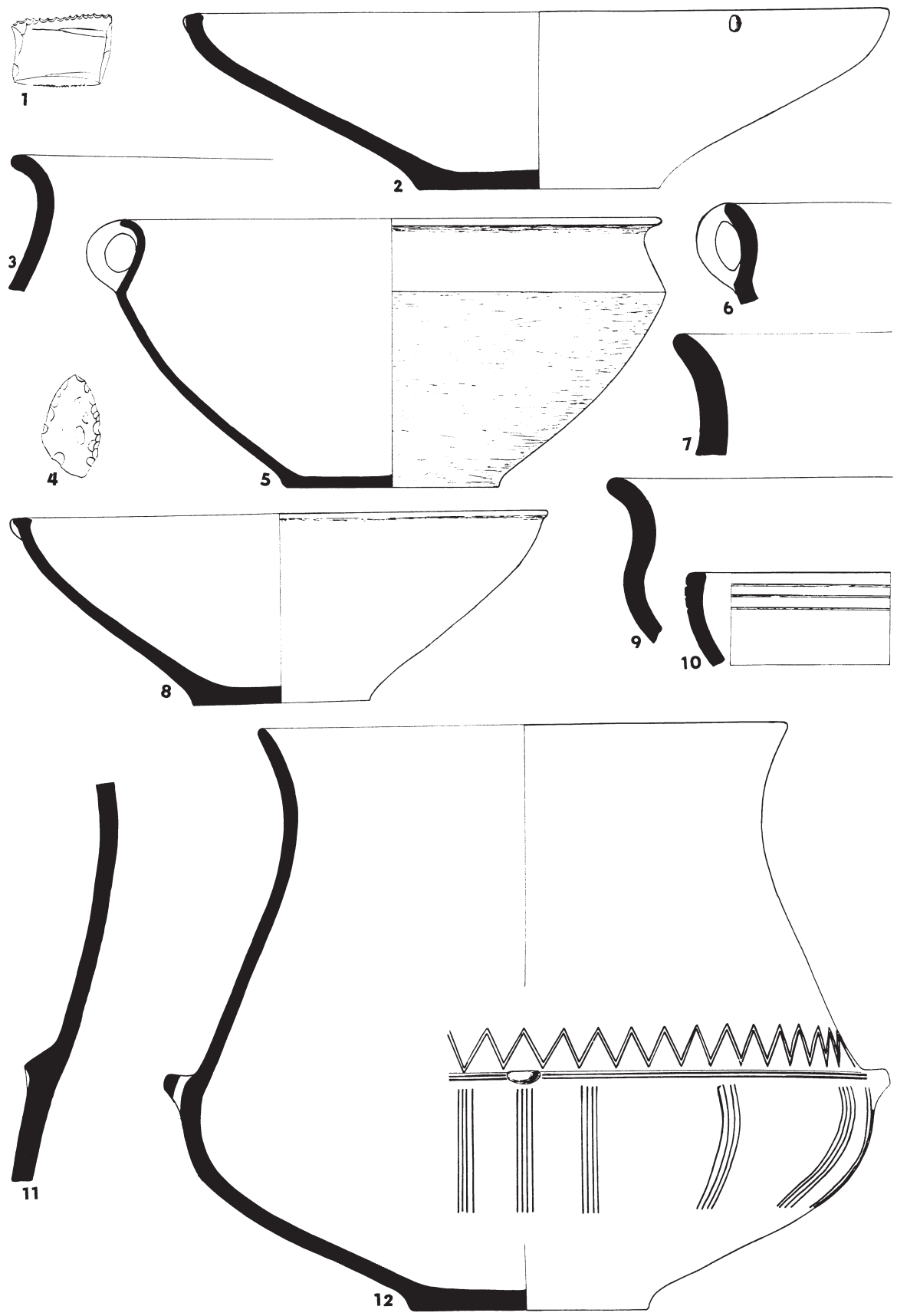

Obr. 7. Šatov - hliník keramičky. Nálezy ÚK z obj. II-42 zkoumaného v r. 1962. Podle Stuchlík 1972, tab. 74.

Fig. 7. Šatov - clay pit of the ceramics factory. Finds of Únětice Culture from Feature II-42, explored in 1962. After Stuchlik 1972, tab. 74. 
zejména v posledních 20 letech. Díky rozsáhlým skrytým plochám bylo během výzkumů odkryto značné množství archeologických situací, což lze ilustrovat např. na záchranných pracích v Modřicích u Brna, kde bylo prozkoumáno na tisíce objektů, z nichž několik set spadá právě do období únětické kultury (Fojtik - Parma 2018, 55).

$\mathrm{V}$ jedné z šatovských cihelen měl být, vedle jiných nálezů, objeven r. 1889 depot několika měděných hřiven doplněných o slitek bronzoviny (Spöttl 1890, 98). Stále nezodpovězenou zůstává otázka ohledně existence standardních hrobů, případně celého pohřebiště únětické kultury. Bud' bylo zničeno dlouhou, několik desítek roků trvající těžbou, nebo skutečná únětická nekropole zatím nebyla objevena. V. Vildomcovi bylo vedoucím podniku sděleno, že několik let před výzkumem 1962 byl objeven hrob obložený kameny, nicméně K. Tihelka (1962b) předpokládá, že většina zmiňovaných hrobů představuje pohřby v sídlištních objektech.

V těsné blízkosti východní hranice katastru Šatova ${ }^{3}$, na výrazné pravobřežní terase potoka Daníže, byly v r. 1991 v profilu těžební stěny opuštěné pískovny zachyceny dva řezy porušeného příkopu od sebe vzdálené 45 metrů. Vedle př́kopu se zde nacházelo i několik únětických objektů. Během letecké prospekce r. 1995 byly v těsném okolí pískovny zaznamenány porostové příznaky svědčící o přítomnosti dalších objektů pravěkého sídliště (Kovárnik 1999a, 514, týž 2015, 106). Zjištěný pravěký příkop, který je datován bud' do únětické kultury, nebo do období věteřovské skupiny (Kovárnik 2015, 106), je 10,60 m široký a dosahuje hloubky 2,90 m (obr. 8). Interpretován je jako součást obloukovitého fortifikačního systému nížinného sídliště ze starší doby bronzové (Kovárnik 2015, 106). Analogii k tomuto způsobu fortifikace rovinné osady ze starší doby bronzové, kdy se obloukovité opevnění přimyká $\mathrm{k}$ hraně terasy, jež na př́írodně chráněném místě tvoří prudký sráz, mů- žeme hledat např. v nedalekých Hrušovanech nad Jevišovkou (Kovárnik 2007) či na slovenské lokalitě Vráble-Fidvár (Bátora - Tóth - Rassmann 2015), areál vymezený nepravidelně kruhovým palisádovým žlabem byl zachycen v Modřicích u Brna (Geislerová - Parma 2018, 257). S nárůstem počtu opevněných sídlišt, at už nížinných, nebo těch na exponovaných polohách, v období únětické kultury se opět ukazuje, že starší, všeobecně přijímaný názor o zničení kulturně-společenského systému (např. Podborský - Vildomec 1972, 88) nositelů únětické kultury nastupující věteřovskou skupinou je dávno překonaný.

Během těžby spraše nebyly ničeny pouze objekty únětické kultury, ale i jámy věteřovské skupiny, což dokládají sporadické nálezy uložené např. v Jihomoravském muzeu ve Znojmě (Stuchliková 1984-II, 112; Tihelka 1952, 328; týž 1962a, 114-115). Zde se nachází předměty objevené zejména během těžby spraše ve třicátých letech. Na první pohled zaujme pěkně vyvedený džbánek s vysokým hrdlem a nízko položenou výdutí, který je po obvodu vklopeného dna opatřen třemi lalůčkovitými nožkami (obr. 9). Zajímavé je také torzo abnormálně velkého koflíku, na jehož těle se nalézají dvě skupiny otvorů. Jedna se nachází pod okrajem, druhá pak nad maximální výdutí. Otvory jsou uspořádány do řady (obr. 10) a provrtány $\mathrm{z}$ vnějš́í strany. S největší pravděpodobností sloužily jako reparační otvory k provlečení šňůrky či drátku (?) ke zpevnění zřejmě popraskané nádoby. Část nálezů spadá jak do starší fáze věteřovské skupiny, tak do jejího mladšího období (Stuchliková 1984-II, 112).

Na osídlení ze starší doby bronzové navazují nálezy středodunajské mohylové kultury ze střední doby bronzové. Stejně jako v případě mnohých předešlých nálezů, je i přesná lokalizace památek SDMK problematická. Ve vídeňském Naturhistorisches Museum je bez bližšího místa nálezu uložený hrot kopí a nezdobený sekeromlat s kotoučovitým týlem (Furmánek 1973, 86). 


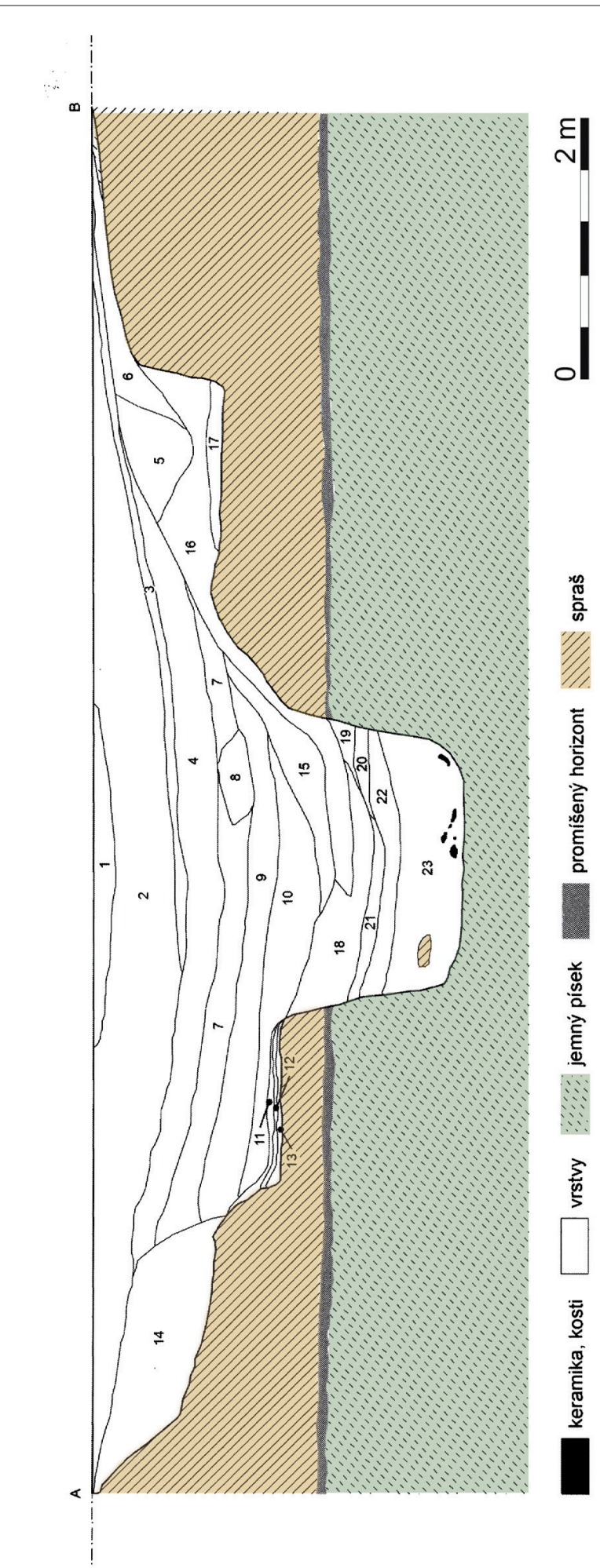

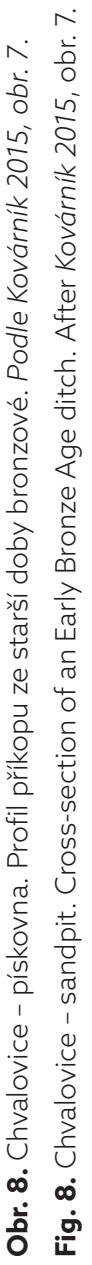




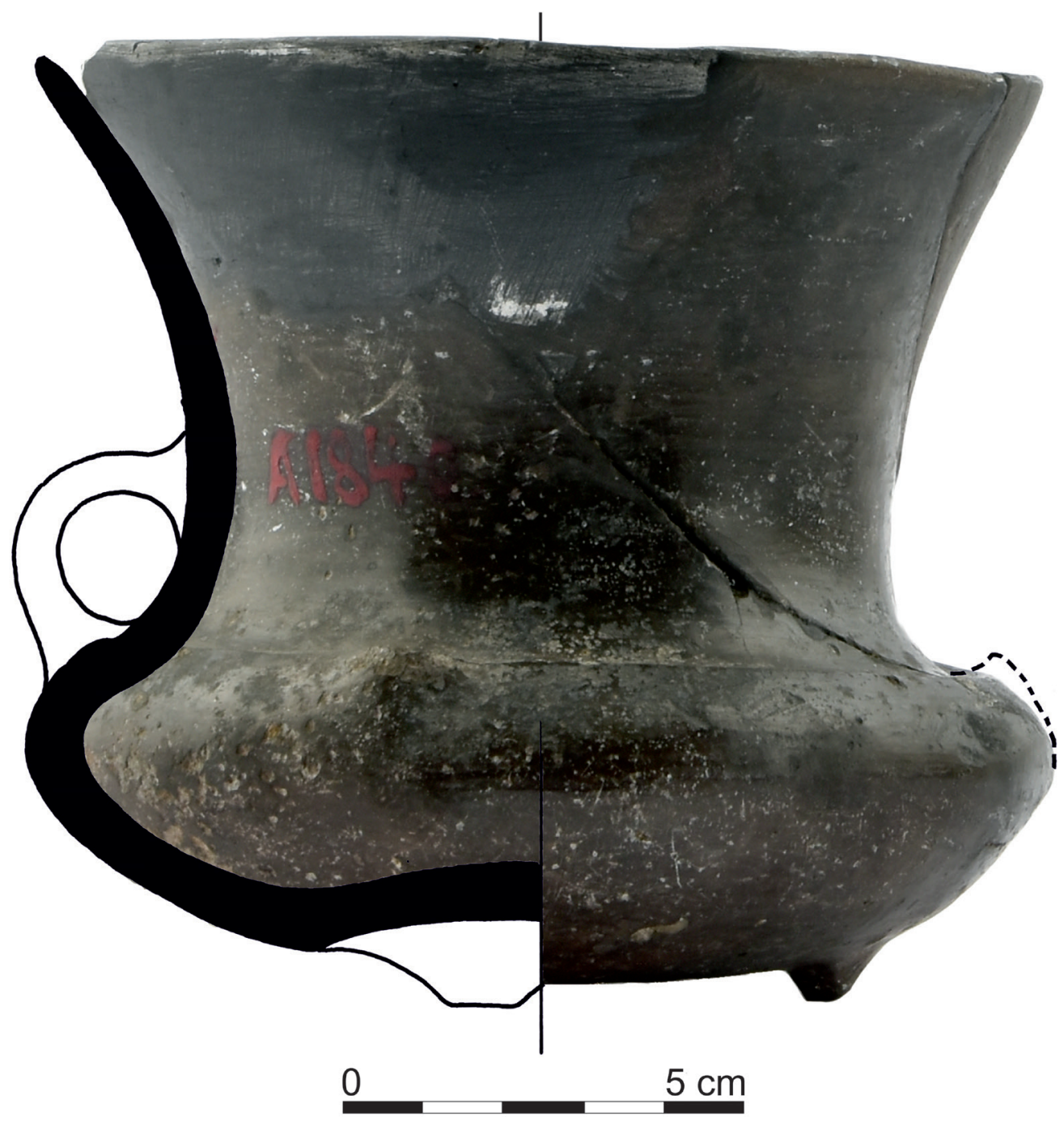

Obr. 9. Šatov. Džbánek VS z jedné z šatovských cihelen/hliníků. Kresba R. Hetflaiš, foto autor.

Fig. 9. Šatov. Ceramic jug of the Věteřov Group. Drawing by R. Hetflaiš, photo by author. 


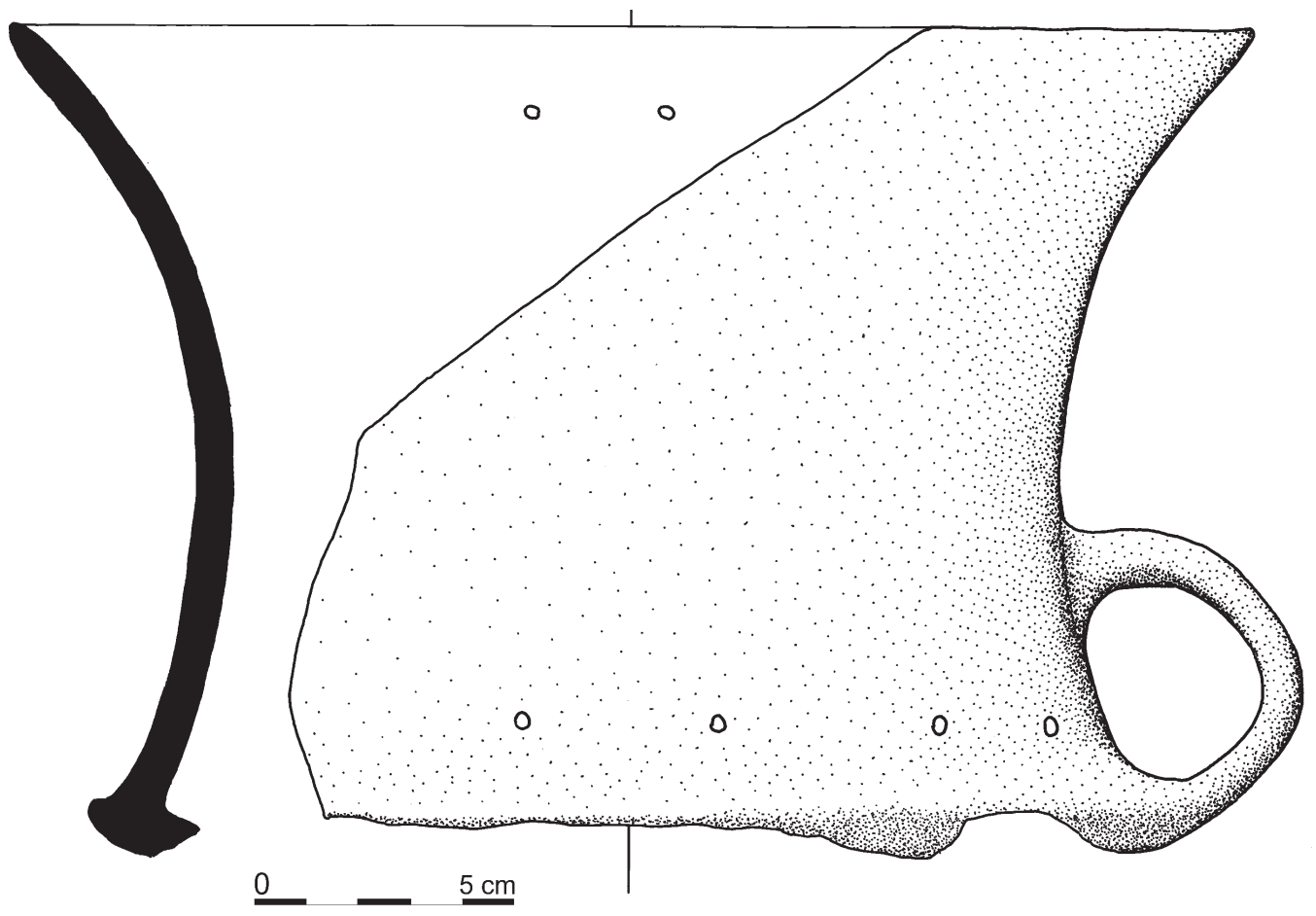

Obr. 10. Šatov. Koflík VS s reparačními otvory z jedné z šatovských cihelen/hliníků. Kresba R. Hetflaiš.

Fig. 10. Šatov. A cup of the Věteřov Group with repair holes. Drawing by R. Hetflaiš.

Tento typ zbraní se vyskytuje na rozsáhlém území od střední Evropy po Karpatskou kotlinu s tím, že největší rozšíření doznaly sekeromlaty kategorie B1 (Stuchlik 1988, 297). Právě do této skupiny předmětů, přesněji do typologické skupiny B1b, kde se nálezy vyznačují dlouhou úzkou čepelí, s nízkou tulejkou a plochým kotoučovitým týlem (Stuchlik 1988, 293), spadá exemplář z Šatova.

Jiné místo, kde byly porušeny objekty SDMK, je v literatuře označováno pouze jako cihelna. Je otázkou, o kterou cihelnu se přesně jednalo. Každopádně byl na popisovaném místě porušen minimálně jeden hrob (?), který obsahoval džbánek zdobený plastickou i vhloubenou výzdobou a poněkud masívní jehlici s kloboučkovitou hlavicí, která je zdobená třemi rytými kruhy na horní straně (obr. 11:6; Ebert, 1925,
348; Hrubý 1950-II, 306; týž 1950-III, tab. 6:4, $5)$. V cihelně se vedle rozrušeného hrobu nacházelo také sídliště SDMK, ze kterého se podařilo zachránit třri nádoby (Hrubý 1950-II, 307; týž 1950-III, tab. 5:1-3). Mezi nádobami vyniká především dvouuchá amfora, jejíž analogie jsou hledány mezi kantaroidními nádobami vyskytujícími se v Karpatské kotlině a v JV Evropě (Stuchlik 2020, 198, obr. 26).

Pohřebiště čítající neznámý počet hrobů bylo porušeno přímo v továrně na výrobu keramického zboží, která se nachází za šatovským nádražím. Přesné datum nálezu a nálezové okolnosti jsou bohužel nejasné (Hrubý 1950-II, 307). Lze uvažovat o tom, že část hrobů byla porušena již v letech 1897-1898, kdy byly odkryty dva hroby s kamennou konstrukcí, z nichž jeden obsahoval jehlici a hrot šípu. Na témže místě 


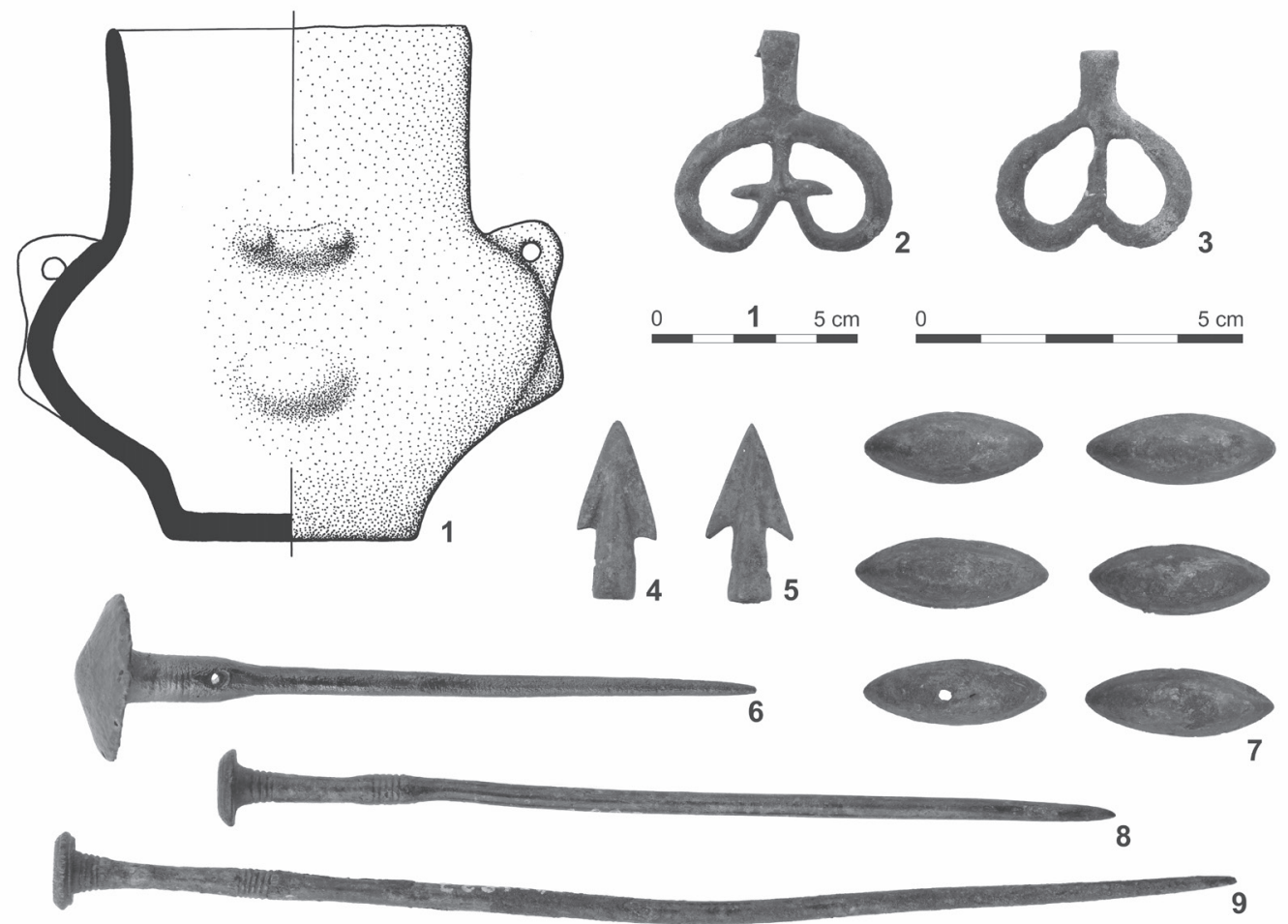

Obr. 11. Šatov. Výběr nálezů z porušených hrobů SDMK. Kresba R. Hetflaiš, foto autor.

Fig. 11. Šatov. Selection of finds of the Middle Danube Tumulus Culture. Drawing by R. Hetflaiš, photo by author.

bylo r. 1902 při stavbě stodoly odkryto pět hrobů se skrčenými kostrami. Hrobové jámy byly obehnány kruhovým věncem z kamenů (Wieder 1925, 170), které snad mohly naznačovat původní překrytí hrobů mohylou. Jeden z hrobů opět obsahoval bronzový hrot šípu. Nálezy z r. 1902 byly po výzkumu uloženy u ředitele školy z blízkého Unterretzbachu L. Mattuly (Wieder 1925, 170). Další hroby, obsahující větší množství bronzové industrie (např. náramky, dva typy pukliček, jehlice) a zlomek jantarového korálku (obr. 11:2-5, 7-9; Hrubý 1950-II, 308-309, tab. $3: 1-9 ; 4)$, byly v továrně rozrušeny před druhou světovou válkou (Stuchlik 2020, 198).

Problematice nálezů SDMK z Šatova a jejich datování věnovalo poměrně velkou pozornost několik badatelů, např. V. Furmánek (1973, 86, 102, 103, 108-113, ad.; obr. 44: 1-13, 16-21, 27-30, 33), V. Hrubý (1950-II, 306-309; týž 1950-III, tab. 3-6) nebo S. Stuchlik (1979-II, 174-179; týž 1979-III, tab. 39-41). Přestože se nepodařilo zachovat jednotlivé uzavřené nálezové celky, je na základě rozboru hmotné kultury výše jmenovaných možné konstatovat, že předměty SDMK z Šatova spadají do období BB1 a BB2.

Období popelnicovích polí je oproti SDMK v Šatově zastoupeno pouze sporadickými nálezy keramiky, které lze snad zařadit do velatické fáze KSPP z mladší doby bronzové (Böhm 1933; Podborský - Vildomec 1972, 215). Bohužel o místě nálezu můžeme pouze spekulovat, 
avšak vzhledem k tomu, co o osídlení v Šatově víme, se nabízí lokalizace do jednoho z těžebních míst ve východní části katastru.

\subsection{Starší doba železná}

O tom, že se na katastru obce podařilo zachytit nálezy ze starší doby železné, víme pouze z krátké právy podané J. Palliardim, který uvádí: „Eine neue Station mit Herdgruben aus der Hallstatt-Periode entdeckte ich bei Schattau" (Palliardi 1895, 57). Bohužel z této věty nelze přesně určit, na kterém místě lokalitu horákovské kultury objevil. Nicméně na základě dosavadních poznatků lze tvrdit, že se pravděpodobně opět jednalo o východní část katastru, kde probíhala těžba spraše a odkud ponejvíce pochází všechny pravěké nálezy známé z území Šatova.

Žárové pohřebiště $\mathrm{v}$ cihelně napravo od dráhy ve směru Retz-Šatov, vzdálené zhruba 200 m od kolejí, popisuje I. Spöttl (1890, 97-99). Pohřebiště čítající nejméně 10 hrobů, které byly patrné v těžební stěně cihelny, a jeden neporušený hrob (Spöttl 1890, Fig. 51) mimo prostor vlastních těžebních prací se podařilo zachytit $\mathrm{v}$ roce 1889 . Podle popisu nálezů a vyobrazení inventáře jednoho z hrobů (Spöttl 1890, 97-99, Fig. 51) bychom mohli uvažovat o zařazení nekropole právě do období horákovské kultury.

\section{Závěr}

V předkládané práci byly v krátkosti shrnuty současné poznatky o pravěkém osídlení zachyceném na katastru obce Šatov. Toto stručné pojednání ukončují nálezy ze starší doby železné, nicméně osídlení zde pokračuje i nadále. Sice není zdokumentované osídlení z doby laténské, ale ve znojemském muzeu se nachází několik předmětů, které lze datovat do doby římské. V Šatovských cihelnách byly údajně r. 1934 rozkopány kostrové hroby z období stěhování národů (Tejral 1982, 218-219), které lze na základě jediné dochované nádoby, džbánu typu Murga (Podborský - Vildomec 1972, tab. LI:10; Tejral 1982, obr. 58:3; tab. XXVIII:1), datovat do druhé poloviny 5. století (Droberjar 2002, 324-325).

Jak je z textu patrné, hlavní těžiště pravěkého osídlení Šatova spočívá v nálezech únětické kultury. Největší výzkum zde proběhl v roce 1962 a je až s podivem, že se doposud nedočkal samostatné studie. Pro dílčí potřeby své disertační práce materiál částečně zpracoval a nakreslil S. Stuchlik (1972), rozbor kamenné štípané industrie pak provedli J. Kopacz s L. Šebelou (2006, 139-141, Tabl. LI-LIV) a L. Kañáková-Hladiková (2011-II, 361-367). Všichni autoři však byli limitováni absencí terénní dokumentace a jakýchkoliv podrobnějších podkladů. Díky nálezu značného množství písemného materiálu, vázanému nejen k výzkumu z r. 1962, který se nachází ve Státním okresním archivu ve Znojmě, vyvstává před autorem článku nebo před jiným specialistou na dobu bronzovou či před studenty archeologie úkol v podobě kompletního a komplexního zpracování této starobronzové lokality.

1) V literatuře se nesprávně objevuje označení trati jako „Hohes Feld“.

2) V. Vildomec (1961) uvádí: „Podle zprávy domácích občanů před lety tu dělaly výzkumy AÚ a jeho zástupce konstatoval, že jde o nevýznamné odpadové jámy, jejichž průzkum z vědeckého stanoviska není rentabilní.“

3) V literatuře, např. Kovárnik 1999a, 514; týž 2015, je lokalita mylně uváděna na katastru Šatova, ve skutečnosti se již jedná o katastr Chvalovic. Nicméně jde o naleziště, které souvisí s osídlením celé terasy táhnoucí se mezi Šatovem a Chvalovicemi. 


\section{Bibliografie}

Bátora, J. - Tóth, P. - Rassmann, K. 2015: Centrálne sídlisko zo staršej doby bronzovej vo Vrábloch. In: Bátora, J. - Tóth, P. (eds.): Ked’ bronz vystriedal med'. Nitra - Bratislava, 123-138.

Bayer, J. 1925: Die ältere Steinzeit in den Sudetenländern, Sudeta I, 21-120.

Böhm, J. 1933: Šatov /Znojmo/. Nálezová zpráva uložená v archivu AÚ AV ČR Praha, č.j. 1614/33.

Březinová, G. - Pažinová, N. 2011: Neolitická osada Hurbanovo-Bohatá, Archeologica Slovaca Monographie XIII. Nitra.

Droberjar, E. 2002: Encyklopedie římské a germánské archeologie v Čechách a na Moravě. Praha.

Ebert, M. (Hrsg.) 1925: Reallexikon der Vorgeschichte, Band II. Berlin.

Fojtik, P. - Parma, D. 2018: Doba bronzová. In: Geislerová, K. - Parma, D. a kol.: Výzkumy - Ausgrabungen 2011-2016. Brno, 53-68.

Furmánek, V. 1973: Bronzová industrie středodunajské mohylové kultury na Moravě, Slovenská archeológia XXI, 25-145.

Geislerová, K. - Parma, D. a kol. 2018: Výzkumy - Ausgrabungen 2011-2016. Brno.

Hrubý, V. 1950: Středodunajské lidstvo mohylové a jeho kultura na Moravě I-III. Rukopis disertační práce. Brno.

Kañáková-Hladiková, L. 2011: Posteneolitická štípaná industrie na Moravě I-II. Rukopis disertační práce. Brno.

Kopacz, J. - Šebela, L. 2006: Kultura unietycka i grupa wieterzowska na Moravach na podstawie materialów. Kraków - Brno.

Kovárnik, J. 1984: Terénní archeologický průzkum na jižní a jihozápadní Moravě, Přehled výzkumů 1982, 94-100.

Kovárnik, J. 1999a: Výsledky letecké archeologie na Moravě v r. 1995, Přehled výzkumů 39 (19951996), 505-516.

Kovárnik, J. 1999b: Poznámka k protoúnětické kultuře na Znojemsku, Sborník prací filozofické fakulty brněnské univerzity M 4, 187-205.

Kovárnik, J. 2007: Trojité opevnění předklasické fáze lidu únětické kultury u Hrušovan n/J, okr. Znojmo, Pravěk NŘ 15, 207-232.
Kovárnik, J. 2015: Opevňovací příkop ze starší doby bronzové u Šatova, okr. Znojmo. Další případy obloukovitých příkopů zjištěných leteckým výzkumem. In: Bátora, J. - Tóth, P. (eds.): Ked' bronz vystriedal med. Nitra - Bratislava, 103-122.

Král, J. 1954: Šatov /okr. Znojmo/. Nálezová zpráva uložená v archivu AÚ AV ČR Brno, č.j. 1251/54.

Ondráček, J. 1967a: Moravská protoúnětická kultura, Slovenská archeológia XV/2, 389-446.

Ondráček, J. 1967b: Šatov (okr. Znojmo). Nálezová zpráva uložená v archivu AÚ AV ČR Brno, č.j. 260/67.

Palliardi, J. 1894: Präehisorischen Forschungen im Jahre 1893, Mitteilungen der Anthropologischen Gesellschaft in Wien XXIV, 32-33.

Palliardi, J. 1895: Thätigkeit im Jahre 1894, Mitteilungen der Anthropologischen Gesellschaft in Wien XXV, 56-57.

Palliardi, J. nedatováno: Inventáře sbírky. Nepublikovaný rukopis uložený v archivu Archeologického ústavu MZM v Brně.

Pavelková, T. 2021: Geologie a geomorfologie Šatova. Nepublikovaný rukopis uložený v Jihomoravském muzeu ve Znojmě. Znojmo.

Piscová, K. 2020: Po stopách šatovské továrny na keramické zboží: historie výroby a proměny výrobního sortimentu. Nepublikovaný rukopis bakalářské práce FF MU. Brno.

Podborský, V. - Vildomec, V. 1972: Pravěk Znojemska. Brno.

Spöttl, I. 1890: Resultate der Ausgraben für die Anthropologische Gesellschaft in Niederösterreich und in Mähren im Jahre 1899, Mitteilungen der Anthropologischen Gesellschaft in Wien XX, 59-100.

Stuchlik, S. 1972: Moravská únětická sídliště. Nepublikovaný rukopis disertační práce. Brno.

Stuchlik, S. 1979: K poznání vzniku a staršího vývoje lidu středodunajské mohylové kultury na jižní Moravě I-III. Nepublikovaný rukopis kandidátské disertace. Brno.

Stuchlik, S. 1988: Bronzové sekeromlaty na Moravě, Památky archeologické LXXIX/2, 269-328.

Stuchlik, S. 1993: Únětická kultura. In: Podborský V. a kol.: Pravěké dějiny Moravy. Brno, 238-257.

Stuchlik, S. 2020: Přehled bádání o mohylové kultuře na Moravě v 19. a 20. století, Acta musei moraviae, Sci. soc. CV-2, 181-230. 
Stuchliková, J. 1984: Problematika vzniku a vývoje věteřovské skupiny na Moravě I-III. Nepublikovaný rukopis kandidátské disertační práce. Brno.

Šmíd, M. 2017: Nálevkovité poháry na Moravě. Pravěk - Supplementum 33. Brno.

Štaffová, M. 1969: Šatov - hliník. Rukopis zprávy uložený v MZA Brno, SOkA Znojmo, Fond Jihomoravské muzeum Znojmo, inv. č. 860/karton 13/fol. 134-136.

Tejral, J. 1982: Morava na sklonku antiky. Praha.

Tihelka, K. 1952: Sídliště věteřovského typu na Moravě, Časopis moravského muzea Brno XXXVII, 313-334.

Tihelka, K. 1962a: Moravský věteřovský typ. II. část (materiál). Študijné zvesti 8. Nitra.

Tihelka, K. 1962b: Šatov (okr. Znojmo). In: Vildomec, V.: Záchranný archeologický průzkum na sídlišti lidu mladšího období keramiky únětické v Šatově. Nálezová zpráva uložená v archivu AÚ AV ČR Brno, č.j. 18/67.
Vildomec, F. 1931: Soupis praehistorických nálezů ze Znojemska, Od Horácka k Podyjí VIII, 3-11.

Vildomec, V. 1961: Hlášení o porušování archeologických objektů v hliníku keramického závodu v Šatově. Rukopis uložený v MZA Brno, SOkA Znojmo, Fond Jihomoravské muzeum Znojmo, karton 13, inv. č. 860, fol. 130, 131.

Vildomec, V. 1962: Záchranný archeologický průzkum na sídlišti lidu mladšího období keramiky únětické v Šatově. Nálezová zpráva uložená v archivu AÚ AV ČR Brno, č.j. 18/67.

Vostrouská, I. 2018: Těšetice-Kyjovice - komunitní areál prvních zemědělců. Nepublikovaný rukopis disertační práce uložený na FF MU. Brno.

Wieder, L. 1925: Markt Schattau. Beiträge zur Heimatkunde. Znaim.

Zápotocký, M. 1957: K problému počátků kultury nálevkovitých pohárů, Archeologické rozhledy IX, 206-208, 217-235. 


\section{Prehistoric occupation of Šatov (Znojmo District)}

The area of Šatov with its favourable natural conditions has already been populated by the Aurignacian Culture in the Palaeoltihic. The first evidence of the presence of hunters and gatherers in this territory was already uncovered in 1908 during extraction of loess for the production of local ceramic ware. Palaeolithic finds were most recently discovered in the spring of 2020 during a garden modification of the extraction wall at the periphery of the old brickworks. Not only Palaeolithic finds but also the other finds of prehistoric cultures at Šatov are tightly related to the extraction of "brick" clay, which started here from the beginning of the ceramics factory at Šatov (Piscová 2020, 7, 22, 83). The extraction of clay gradually uncovered large areas with many traces of various prehistoric cultures. From the Šatov brickworks we know finds of the Linear Pottery Culture (Fig. 3), Moravian Painted Ware Culture and Funnel Beaker Culture (Fig. 4). The apex of settlement activity falls within the Early Bronze Age. At the time of the Unětice Culture, the right bank of the local stream Daníž was occupied by an extensive settlement, of which about 180 sunken features were explored. This high number of settlement features made this village for some time the largest Únětice-Culture settlement site in Moravia (Figs. 5-8; Stuchlik 1993, 249). In 1889, a hoard of several copper ingots supplemented with a piece of bronze casting scrap was found in one of the brickworks at Šatov (Spöttl 1890, 98). The existence of a cemetery of the Únětice Culture is still a matter of question. The settlement of the Únětice Culture was fluently replaced by the Věteřov Group, whose finds are so far not really numerous and are limited to objects discovered in about the 1930s (Figs. 9, 10). It is possible that some features from the excavations in 1962 might fall within the period of the Věteřov Group, which will be verified by new revision research. Features belonging to the Middle Danube Tumulus Culture were disturbed at several places in the eastern part of the studied cadastre. Among them were both graves and settlement features (Fig. 11; Hrubý 1950-II, 306; id. 1950-III, tab. 6:4, 5). The Late and Final Bronze Age and Early Iron Age are only sporadically present. It is well possible that a cemetery of the Horákov Culture might have been disturbed about 200 metres to the right of the railway from Retz to Šatov (Spöttl 1890, 97-99). Other relics of prehistoric or early historic occupation in the vicinity of Šatov date back to the Roman Era and the Migration Period. 
Rožnovský

Pravěké osídlení Šatova (okr. Znojmo)

\section{David Rožnovský}

- Jihomoravské muzeum ve Znojmě, p. o.

Přemyslovců 129/8, 66902 Znojmo

archeolog@muzeumznojmo.cz 